\title{
Reviewing the Speaker's Decision: A Brief Synopsis of UDM v Speaker of the National Assembly 20175 SA 300 (CC)
}

\section{P.E.R}

Pioneer in peer-reviewed, open access online law publications

Author

Bradley Slade

Affiliation

Stellenbosch University

South Africa

Email

bvslade@sun.ac.za

Date Submission

31 March 2020

Date Revised

8 March 2021

Date Accepted

8 March 2021

Date published

29 March 2021

Editor Prof A Gildenhuys

How to cite this article

Slade BV "Reviewing the Speaker's Decision: A Brief Synopsis of UDM $\checkmark$ Speaker of the National

Assembly 20175 SA 300 (CC)" PER / PELJ 2021(24) - DOI http://dx.doi.org/10.17159/17273781/2021/v24i0a8111

Copyright

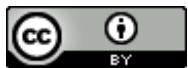

DOI

http://dx.doi.org/10.17159/1727$3781 / 2021 / v 24 i 0 a 8111$

\begin{abstract}
In United Democratic Movement $v$ Speaker of the National Assembly 20175 SA 300 (CC), the Constitutional Court set out certain factors that the Speaker of the National Assembly must consider when deciding the manner in which voting in a motion of no confidence proceeding must be conducted. These factors would ostensibly also be relevant when the Speaker's decision as to the proper voting procedure is reviewed in future.

This note considers the law governing the review of the Speaker's decisions and finds that although the Speaker's decision is reviewable in South African law, after the UDM decision there is still uncertainty as to whether the Speaker's decision can be reviewed only on the basis of legality or whether it constitutes administrative action reviewable in terms of PAJA. Furthermore, the Court's exposition of certain factors against which the Speaker's decision can now be reviewed creates uncertainty as to whether the review in terms of legality is a basic rationality review as is generally the case or a stricter form of review closer to review that is possible under PAJA.

The argument is that the potential of reviewing the Speaker's decision on the basis of a number of factors that in totality appears to set out a test that is stricter than a basic rationality test may hold severe implications for the separation of powers doctrine, as it now appears that the Court is increasing its supervisory jurisdiction in a manner that is not fully substantiated. Although the Court, or courts in general, has the power to review the exercise of public power in a system of constitutional supremacy, it should consider the impact that its judgments may have on co-equal branches of government, as a failure to do so may negatively impact on the relationship between the different branches of government and dilute the already frayed separation of powers doctrine.
\end{abstract}

\section{Keywords}

Separation of powers; judicial review; judicial restraint; legality; rationality; administrative law. 


\section{Introduction}

In United Democratic Movement $v$ Speaker of the National Assembly (hereafter UDM), ${ }^{1}$ the Constitutional Court handed down the following order: "The Speaker's decision of 6 April 2017 that she does not have the power to prescribe that voting in the motion of no confidence in the President be conducted by secret ballot is set aside." This is not the first time a decision of the Speaker of the National Assembly has been reviewed and set aside. ${ }^{2}$ However, in UDM the Court not only set aside the Speaker's decision but it also set out a framework within which the Speaker will arguably have to make future decisions regarding the manner of voting in a motion of no confidence. This framework, which consists of a number of factors, will also be relevant when the Speaker's decision as to the proper voting procedure is reviewed in future. Although it seems generally accepted that the Speaker's decision is reviewable in terms of legality, case law does not totally close the door on categorising the Speaker's decision in certain instances as constituting administrative action that is reviewable in terms of the Promotion of Administrative Justice Act (hereafter PAJA). ${ }^{3}$ Furthermore, the UDM decision does hint at a stricter form of review, which is possible under PAJA but not generally available in terms of legality.

The UDM decision ultimately deals with the National Assembly's obligation to hold the President and the Executive authority accountable in terms of section 102 of the Constitution of the Republic of South Africa, 1996 (hereafter the Constitution). This decision also concerns the role of the Constitutional Court in settling disputes amongst political parties and office bearers in the National Assembly concerning the proper interpretation of the Constitution and the Rules of the National Assembly. ${ }^{4}$ Some commentators have already commented positively on the Court's ultimate finding. ${ }^{5}$ This contribution, however, does not focus on the Court's ultimate finding and the order it gave, the exact implications that the orders may have on separation of powers, and the outer boundaries of the Court's review powers where it concern internal parliamentary procedures and processes. Instead, the

\footnotetext{
Bradley V Slade. BComm LLB LLM LLD (US). Associate Professor, Department of Public Law, Faculty of Law, Stellenbosch University, South Africa. Email: bvslade@sun.ac.za. ORCID ID: https://orcid.org/0000-0001-8855-1269.

$1 \quad$ United Democratic Movement v Speaker of the National Assembly 20175 SA 300 (CC) (hereafter UDM) para 97.

2 See Lekota $v$ Speaker of the National Assembly 20154 SA 133 (WCC); Malema v Chairperson of the National Council of Provinces 20154 SA 145 (WCC); Chairperson of the National Council of Provinces v Malema 20165 SA 335 (SCA). Promotion of Administrative Justice Act 3 of 2000 (hereafter PAJA).

Parliament Rules of the National Assembly.

Rautenbach 2018 TSAR 13; Woolman 2018 CCR 155.
} 
contribution focusses on the Court's explanation in the latter, arguably obiter part of the judgment that relates to the factors, or "legal position and conditionalites", ${ }^{6}$ that would now guide the Speaker's decision as to the proper voting procedure in a motion of no confidence.

This note will consider what is meant when it is stated that the Speaker's decision is reviewable in terms of legality, and what is the impact of the Court's framework that would guide the Speaker's decision whether to order a secret ballot in motion of no confidence proceedings. This note will show that the Court, in setting out these factors, expanded the notion of rationality review to be more than simply a "minimum threshold requirement"7 without addressing the potential separation of powers issues that arise from such an understanding. It therefore follows on the argument that Lauren Kohn put forward on the basis of a series of judgments where rationality review was seemingly expanded. Kohn ${ }^{8}$ argues that in developing "an expansive conception of rationality review - in the absence of meaningful engagement with the prescripts of the separation of powers doctrine - and thereby increasing their reservoir of judicial power, the courts may be perceived to be expanding their supervisory review jurisdiction in a manner that amounts to an affront to this doctrine." As the separation of powers doctrine has come under intense scrutiny, especially in the light of Economic Freedom Fighters $\checkmark$ Speaker of the National Assembly (hereafter EFF), ${ }^{9}$ this note discusses the Court's potential expanded notion of rationality review in UDM and notes the possible implications on the doctrine of the separation of powers, implications not considered by the Court but which may have longer term negative consequences.

\section{UDM v Speaker of the National Assembly: The facts}

The UDM decision dealt with section 102 of the Constitution, which allows the National Assembly to remove the Executive authority with or without the President through a motion of no confidence supported by at least a majority of the members of the National Assembly. This decision ostensibly follows Mazibuko v Sisulu (hereafter Mazibuko), ${ }^{10}$ where the Constitutional Court held that the Rules of the National Assembly were unconstitutional because

\footnotetext{
$6 \quad$ UDM para 94.

$7 \quad$ Pharmaceutical Manufacturers Association of South Africa: In re Ex Parte President of the Republic of South Africa 20002 SA 674 (hereafter Pharmaceutical Manufacturers) para 90.

$8 \quad$ Kohn 2013 SALJ 810, 812. Footnotes and emphasis omitted.

$9 \quad$ Economic Freedom Fighters $v$ Speaker of the National Assembly 20182 SA 571 (CC) (hereafter EFF).

10 Mazibuko v Sisulu 20136 SA 249 (CC) (hereafter Mazibuko).
} 
they subjected a member's constitutional right to have a motion of no confidence debated and voted on in the Assembly to the consent of the Programme Committee. ${ }^{11}$ The National Assembly duly amended the Rules. ${ }^{12}$ The contestation concerning the rules and procedures where it concerns instituting a motion of no confidence in terms of section 102, however, did not end there.

In early 2017 the United Democratic Movement instituted a motion of no confidence against the President for dismissing the finance minister and his deputy, which contributed to the downgrade of the South African economy to "junk status". ${ }^{13}$ The amended Rules were applied and the Speaker duly scheduled the motion of no confidence for debate and voting. The United Democratic Movement, however, requested that the vote take place via secret ballot. The Speaker refused the request, submitting that neither the Constitution nor the Rules provide for a vote in a motion of no confidence to take place via secret ballot. The Speaker relied on Tlouamma $v$ Mbete, Speaker of the National Assembly (hereafter Tlouamma), ${ }^{14}$ where the High Court was requested to grant declaratory relief to the effect that the Speaker had the discretion, in terms of the Rules, to order a secret ballot. The High Court held that since the Constitution and the Rules do not specifically allow for a secret ballot in this instance, it did not have the power to prescribe to the National Assembly how to conduct its voting procedure as that would offend against the provisions of section 57 of the Constitution as well as the doctrine of separation of powers. ${ }^{15}$ As such, the Speaker maintained that the Constitution and the Rules do not allow for a secret ballot.

Therefore, in the UDM decision there was a disagreement between members in the National Assembly and the Speaker about the proper interpretation of the Constitution and the Rules. The disagreement centred on whether the Constitution or the Rules require, permit or prohibit voting on a motion of no confidence via secret ballot. The Court noted that the parties approached it to clarify Parliament's power, and rightly so as any dispute can be resolved before a court.

11 There is some debate amongst scholars as to the correctness of the Court's review of internal parliamentary proceedings in this case: see Cachalia 2015-2016 NYL Sch $L R e v$, which is critical of the Court's reasoning, and Okpaluba 2015 CILSA, which is supportive of the Court's supervisory jurisdiction also in internal parliamentary proceedings.

12 See Venter 2014 TSAR 407.

13 UDM para 13.

14 Tlouamma v Mbete, Speaker of the National Assembly 20161 SA 634 (WCC) (hereafter Tlouamma).

15 See particularly Tlouamma para 123. 
The ultimate decision of the Court was that the Constitution and the Rules permit a secret ballot and that the Speaker has the discretion which voting procedure to adopt. The Court referred the United Democratic Movement's request for a motion of no confidence by secret ballot to the Speaker to make a decision afresh, instead of ordering a secret ballot as was requested. The Court reasoned that ordering a motion of no confidence to take place via secret ballot would offend the separation of powers doctrine. In this regard, and in line with earlier precedent, ${ }^{16}$ the judgment is relatively straightforward and cannot easily be faulted. Rautenbach ${ }^{17}$ described the judgment as "unimpeachable" - stating that "the correctness of [the Court's] conclusion cannot be questioned". The judgment has also been commended for re-affirming the National Assembly's constitutional duty of accountability, ${ }^{18}$ and reminding the Executive that public power must be exercised in a justifiable manner. ${ }^{19}$

The judgment of the Court in UDM, however, did not end with the Court's clarification of whether the Constitution and the Rules permit a secret ballot and an affirmation that the Speaker has the authority to decide the appropriate voting procedure. After having determined that the Constitution and the Rules permit a secret ballot and that the Speaker has the power to decide which voting procedure to adopt, the Court discussed "crucial factors" that would in essence dictate the Speaker's determination as to the proper voting procedure that must be adopted. ${ }^{20}$

The reason why the Court chose to deliberate on such factors can probably be attributed to the opposing views of the United Democratic Movement and the Speaker as to the proper remedy that should be awarded in this particular case. The applicant argued very strongly that in the exceptional circumstances of the case, the Court should direct the Speaker to order a secret ballot as the Speaker had demonstrated that she is "conflicted and unable to differentiate between her roles as Speaker and that of Chairperson of the ANC."21 Since the only reason the Speaker refused to order a secret ballot was because she believed she did not have the

\footnotetext{
16 See for instance Mazibuko, where the Court declared certain Rules inconsistent with the Constitution, and left it to the National Assembly to decide how to rectify it. Rautenbach 2018 TSAR 1-17. Woolman 2018 CCR 155-192. Also see Banda 2018 SAIPAR Case Review 16-20. Banda 2018 SAIPAR Case Review 16-20.

UDM para 94.

Constitutional Court 2017a https://collections.concourt.org.za/bitstream/ handle/20.500.12144/3901/Applicant\%27s\%20Heads\%20of\%20Argument.pdf?seq uence=27\&isAllowed=y (hereafter Applicant's Heads of Argument) para 95.3.
} 
authority in law to do so, the applicant argued that "there is no reason why a secret ballot should not be ordered" by the Court. ${ }^{22}$

The Speaker, on the other hand, argued equally strongly, on the basis of concerns about the separation of powers, that an order directing a secret ballot would not be an appropriate remedy. The Speaker noted that the Court should intervene only in "matters that fall within the domain of the national legislature ... [if] ...mandated by the Constitution", and that any "intrusion" must be to the extent that it is necessary. ${ }^{23}$

The Court seemed to have accepted the Speaker's argument about the separation of powers, as it noted that the "power to prescribe the voting procedure in a motion of no confidence reposes in the Speaker, [which] accords with the dictates of separation of powers. It affirms the functional independence of Parliament to freely exercise its section 57 powers."24 However, in light of the very strong arguments on the part of the United Democratic Movement in light of the relief requested (which was also supported by some of the other respondents), ${ }^{25}$ the Court may have found it appropriate, in general, to discuss the pertinent factors that would guide the Speaker's decision when deciding on the appropriate voting procedure in a motion of no confidence.

Although the judgment did not contain a list of factors, a list appears in the media summary to the judgment. These factors can be traced back to the judgment. In exercising her discretion the Speaker would have to take the following into account:

(a) whether the chosen voting procedure would allow Members of the National Assembly to vote according to their conscience and in the furtherance of the best interests of the people; (b) whether the prevailing circumstances are either peaceful, or toxified and potentially hazardous; (c) the imperative of the Speaker's impartiality must be consciously factored into the decision-making

22 Applicant's Heads of Argument para 95.5.

23 Constitutional Court 2017c https://collections.concourt.org.za/bitstream/ handle/20.500.12144/3901/First\%20Respondent\%27s\%20Heads\%20of\%20Argum ent.pdf?sequence=29\&isAllowed $=y$ (First Respondent's Heads of Argument) para 82. See also National Treasury v Opposition to Urban Tolling Alliance 20126 SA 223 (CC) para 44 where the Court held that courts "must refrain from entering the exclusive terrain of the Executive and the Legislative branches of Government unless the intrusion is mandated by the Constitution itself."

24 UDM para 69.

25 See for instance the Economic Freedom Fighter's position, as made clear in the Fifth Respondent's Heads of Argument (https://collections.concourt.org.za/bitstream/ handle/20.500.12144/3901/Fifth\%20Respondent\%27s\%20Heads\%20of\%20Argum ent.pdf? sequence $=73$ \&isAllowed $=y$ ), supporting the first applicant's notice of motion, which includes directing the Speaker to conduct a secret ballot in a motion of no confidence. 
process; (d) the effectiveness of a motion of no confidence as an accountability and consequence-management tool must be enhanced by the chosen voting procedure; (e) the possibility of corruption or bribes in the event of a secret ballot must be considered; (f) the need for the value of transparency to find expression in the passing of the motion must be taken into account; $(\mathrm{g})$ the decision must be rationally connected to the purpose of a motion of no confidence and should not be made arbitrarily. ${ }^{26}$

Sewpersadh and Mubangizi ${ }^{27}$ argue that the Court effectively rendered the Speaker's decision "subject to review against clear and judicially defined factors." As it has been established in case law that the Speaker's decision, as an exercise of public power, is reviewable in terms of legality, ${ }^{28}$ it is worth investigating whether the Court's discussion of the factors may have any impact on the Speaker's discretion to decide on matters relating solely to the operation of the National Assembly, and the standard or level of review to which the Speaker's decision may be subjected to in future. These consequences may not have been considered by the Court, and potentially point towards a lack of institutional restraint by the Court. ${ }^{29}$ Although claiming that the Speaker must use her power for the effective exercise of Parliament's accountability function, the Court has arguably expanded its supervisory jurisdiction without considering any adverse effects this may have on the separation of powers doctrine ${ }^{30}$

\section{Review of the Speaker's powers}

The question as to whether the Speaker's decision, where it concerns internal Parliamentary procedures, is reviewable as an administrative action in terms of PAJA or legality has been considered by the courts.

In Lekota $v$ Speaker of the National Assembly, (hereafter Lekota) ${ }^{31}$ the High Court had to decide whether the Speaker's request that the applicant, a Member of Parliament, withdraws certain statements made in the National Assembly during a budget vote, and to withdraw from the National Assembly after refusing to withdraw the statements, should be set aside upon review. The Court stressed that the Speaker must "perform her functions in

26 Constitutional Court 2017d https://collections.concourt.org.za/bitstream/ handle/20.500.12144/3901/Summary\%20of\%20judgment.pdf?sequence=90\&isAllo wed $=y$ (Summary of Judgment).

$27 \quad$ Sewpersadh and Mubangizi 2017 LDD 219.

28 See the discussion of judgments at 3 below.

29 See Cachalia 2015-2016 NYL Sch L Rev 379-406.

30 See generally Cachalia 2015-2016 NYL Sch L Rev 401-405 for a discussion on the implications, especially the negative implications for the separation of powers when courts do not show appropriate institutional restraint.

$31 \quad$ Lekota $v$ Speaker of the National Assembly 20154 SA 133 (WCC) (hereafter Lekota). 
accordance with the constitutional principle of legality which requires her to act within the power conferred upon her by the law, and, in particular the Constitution."32 To support this statement, the Court referred to Democratic Alliance $v$ President of the Republic of South Africa (hereafter Democratic Alliance), ${ }^{33}$ where the Constitutional Court stated that public officials "may exercise no power and perform no function beyond that conferred ... by law and that the power must not be misconstrued." 34 In the Democratic Alliance decision the Court further held that any "decision must be rationally related to the purpose for which the power was conferred."35 The High Court therefore accepted that the Speaker's decision can be reviewed on the basis of legality.

The High Court also dismissed the applicant's argument that the Speaker's ruling constitutes administrative action that is reviewable under PAJA. The Court held that PAJA does not apply as the decision was made when Parliament was fulfilling a legislative function, which is expressly excluded under the definition of administrative action in section 1 of the PAJA. ${ }^{36}$

Malema $v$ Chairperson of the National Council of Provinces ${ }^{37}$ also dealt with the review of the Chairperson of the National Council of Provinces' decision to request the applicant to withdraw certain statements and, upon failing to do so, to order him to vacate the House. ${ }^{38}$ The applicant, a Member of Parliament, made certain statements during the debate on the President's annual State of the Nation Address that were deemed by the Chairperson to be unparliamentary. The applicant argued that the Chairperson's decision must be reviewed in terms of PAJA. ${ }^{39}$ The Chairperson argued that PAJA does not apply to her rulings, and if it did, that there was no basis upon

$32 \quad$ Lekota para 29.

33 Democratic Alliance v President of the Republic of South Africa 20131 SA 248 (CC) (hereafter Democratice Alliance).

34 Democratic Alliance para 27. This statement (with reliance on the earlier Fedsure Life Assurance v Greater Johannesburg Transitional Metropolitan Council 19991 SA 374 (CC) (hereafter Fedsure) para 58) was in relation to the exercise of executive power but applies equally to the power of the Speaker, as in Fedsure the principle of legality was made to apply to the Legislature and the Executive. Democratic Alliance para 27.

See Lekota paras 47-48.

Malema $v$ Chairperson of the National Council of Provinces 20154 SA 145 (WCC) (hereafter Malema).

The presiding officer in this case was the Chairperson of the National Council of Provinces, who presided over a joint sitting of the National Assembly and National Council of Provinces, but the principles discussed in this case may be equally applicable to the Speaker when the National Assembly is sitting unicamerally. The applicant argued that the decision of the Chairperson was unlawful in term of $P A J A$ as the chairperson was "biased, her decision was based on a material error of law ... [and] that she had acted in bad faith for an ulterior purpose". See Malema 28. 
which to set it aside. The High Court noted that it had to determine whether the Chairperson's decision constituted administrative action or whether it was excluded through the exemption in PAJA for "legislative functions" of Parliament. However, since it is accepted that the presiding officer's decision is reviewable in terms of legality, the Court found it unnecessary to determine whether PAJA was applicable. ${ }^{40}$ On appeal the Supreme Court of Appeal did not address the issue as to whether the Chairpersons' decision may be reviewable under PAJA but accepted that the Chairperson's decision is reviewable in terms of legality. ${ }^{41}$

PAJA makes it clear that the "legislative functions of Parliament" are excluded from the definition of administrative action and are therefore not reviewable in terms of PAJA. ${ }^{42}$ What is less clear is whether the term "legislative functions" is interpreted broadly to include the passing of legislation, debating issues of national importance, and the National Assembly's exercise of its accountability and oversight functions, ${ }^{43}$ or whether it has a narrower interpretation related only to the passing of legislation. If the latter narrower interpretation is adopted, it may render decisions of the Speaker made during a debate on issues of national importance and when the National Assembly exercises its accountability and oversight functions susceptible to review under administrative law. In Malema the High Court did not definitely provide an answer as to whether the decision of the Chairperson made during a debate regarding an issue of national importance is reviewable under PAJA. The Supreme Court of Appeal also did not address this issue as it simply reviewed the decision of the Chairperson in terms of legality. Although most courts refer to the Speaker's decision as having to be rational, ${ }^{44}$ it still remains unclear as to whether there is the possibility that the Speaker's decision may be reviewable in terms of PAJA in the case where a decision was made when Parliament was debating an issue of national importance or when the National Assembly is exercising its accountability function.

Malema para 47.

41 Chairperson of the National Council of Provinces v Malema 20165 SA 335 (SCA) para 16.

42 Section 1 of PAJA.

43 These are the functions of Parliament as per s 42(3) of the Constitution of the Republic of South Africa, 1996 (the Constitution).

44 See for instance Tlouamma paras 115-116. Although the court at para 115 stated that the Speaker's decision was "reasonable and rational", the court still had regard to rationality review as the appropriate standard of review. 
The difference between review under PAJA on the one hand and review under legality on the other hand has been well documented. ${ }^{45}$ What is of importance for the purposes of this paper is the fact that review under administrative law is more "searching"46 than review under legality. Subjecting the decision of the Speaker to review under PAJA in cases where decisions were made as the legislature was fulfilling its legislative function as broadly defined, may raised sensitive separation of powers issues, especially since the reason for the exclusion of legislative functions in section 1 of PAJA was the was the separation of powers doctrine. ${ }^{47}$

It is against this background that the factors set out by the Court to assist the Speaker in determining which voting procedure to adopt should be understood. Although the decision rests with the Speaker, her discretion is "subject to crucial factors that are appropriately seasoned with considerations of rationality."48

\section{Analysis of the review of the Speaker's decision in light of UDM}

The principle of legality was identified by the Constitutional Court as part of the rule of law, a founding principle in section 1 of the Constitution. ${ }^{49}$ Simply put, it means that public power can be exercised only if, and in so far as, the power to do so has been conferred upon the functionary by the law. ${ }^{50}$ In UDM the Speaker maintained that she did not have the power in terms of the Constitution or the Rules (the "law") to order a secret ballot. The Court, having found differently, made it clear that the Speaker indeed has the power, in terms of a particular interpretation of the Constitution and the Rules, to order a secret ballot. ${ }^{51}$

\footnotetext{
45 See Hoexter Administrative Law 114-125.

$46 \quad$ Hoexter Administrative Law 124. In Minister of Defence and Military Veterans $v$ Motau 20145 SA 69 (CC) para 27, Khampepe J stated that a review of administrative action under PAJA is subject to a higher level of scrutiny than a review of public power under legality.

$47 \quad$ Klaaren and Penfold "Just Administrative Action" 63-66.

$48 \quad$ UDM para 94.

49 Price 2013 SALJ 649; Hoexter Administrative Law 121.

In Fedsure para 58 the Court held "it is central to the conception of our constitutional order that the Legislature and Executive in every sphere are constrained by the principle that they may exercise no power and perform no function beyond that conferred upon them by law." UDM para 97.
} 
The substantive component of legality is that of rationality, ${ }^{52}$ which extends beyond the lawfulness of the decision but also renders the decision or actions of public officials reviewable. ${ }^{53}$ Review on the basis of legality is important as it enables the courts, as the ultimate guardians of the Constitution, to review the decisions of public officials, such as those of the Speaker, ${ }^{54}$ in cases where the decision may not be reviewable in terms of PAJA. ${ }^{55}$ According to Price, rationality operates "as a minimum standard a constitutional baseline - that applies even where no fundamental right or other constitutional standard is directly applicable." 56 In Pharmaceutical Manufacturers the Court held that the President's decision must be objectively rational; if not, it is liable to be set aside. ${ }^{57}$ In that decision the Court also stressed that if there is a rational connection between the decision and a legitimate government purpose, courts should not easily replace the decision maker's decision with one of its own. ${ }^{58}$ In that regard, the Court held that it would only rarely make a finding that a decision was objectively irrational. ${ }^{59}$ It is therefore clear that once a link or nexus between the decision and the legitimate government purpose is found, the Court would not easily set aside the decision based on irrationality. ${ }^{60}$

In relation to the factors the Court set out in UDM that would ultimately guide the Speaker's determination in deciding whether an open or secret ballot should be held, Rautenbach ${ }^{61}$ points out that it is unclear which legal standard the Speaker will have to apply. Rautenbach ${ }^{62}$ argues that it is not clear whether the Court had in mind a "basic means-end rationality test" or "a stricter standard" that would ask which alternative procedure (open or secret ballot) would "contribute certainly, probably, possibly, substantially or reasonably better towards achieving the purpose of voting on no confidence

52 Van der Sijde Reconsidering the Relationship between Property and Regulation 213214.

$53 \quad$ Price 2013 SALJ 656.

54 In Pharmaceutical Manufacturers para 90 the Court described rationality as "a minimum requirement applicable to the exercise of all public power by members of the executive and other functionaries." Own emphasis.

55 Price 2013 SALJ 657.

56 Price 2010 SAPL 346.

57 Pharmaceutical Manufacturers paras 89-89.

58 Pharmaceutical Manufacturers paras 86-89. O'Regan 2012 SAJHR 128 states that "rationality does not permit courts to substitute their opinion as to what would be appropriate for that of the government."

59 Pharmaceutical Manufacturers para 90.

60 Pharmaceutical Manufacturers para 90; O'Regan 2012 SAJHR 128.

61 Rautenbach 2018 TSAR 14.

62 Rautenbach 2018 TSAR 13. 
motions." ${ }^{63}$ Sewpersadh and Mubangizi 64 compliment the Court for setting out the prescribed set of factors that the Speaker must take into account. The authors argue that the Court made it clear that the decision of the Speaker is not an unfettered one, but that the decision is subject to review against certain factors, "which factors bear a striking resemblance to the well-known administrative law principles."65 Although I do not read the authors' argument as one suggesting that the Speaker's decision is reviewable in terms of PAJA, taken with Rautenbach's argument it does perhaps point towards an expanded notion of rationality that may be at play when the Speaker's decision is reviewed in future.

The expanded notion of rationality potentially goes further than merely asking whether there is a nexus or link (some "rhyme or reason") ${ }^{66}$ between the decision and the purpose. It may in this instance also include the question whether the Speaker took all the relevant considerations into account in arriving at her decision. ${ }^{67}$ These considerations are now defined by the Court, and include whether the circumstances are peaceful or toxified, and whether the chosen voting procedure enables accountability or, alternatively, transparency ${ }^{68}$ It may also include questioning whether the Speaker acted with an ulterior motive in arriving at the decision. These questions, which go beyond merely asking whether there is a rational link between the decision and the purpose for which the decision was taken, resemble review under PAJA, particularly review in terms of section 6(2)(e) of PAJA. This relates to the review of an administrator's decision because "irrelevant considerations were taken into account or relevant considerations were not considered" 69 or because the decision was taken "for an ulterior purpose or motive". ${ }^{70}$

Although accepting that review under legality is important in South African constitutional democracy as it enables the review of decisions made by public officials that are not reviewable under PAJA, Price does note certain concerns with regard to what he calls the "growth of constitutional legality and rationality". ${ }^{71}$ An important concern regarding the move away from the basic rationality ("rhyme or reason") test is the court's "unwarranted

Rautenbach 2018 TSAR 14. Own emphasis.

Sewpersadh and Mubangizi 2017 LDD 219.

Sewpersadh and Mubangizi 2017 LDD 219.

O'Regan 2012 SAJHR 127.

Price 2013 SALJ 653-654.

UDM para 80.

Section 6(2)(e)(iii) of PAJA.

Section 6(2)(e)(ii) of PAJA.

Price 2013 SALJ 657. 
intrusion into the legitimate constitutional spheres of the executive and legislative branches of government."72 This is ultimately a concern about the separation of powers.

The application of an expanded notion of "rationality proper"73 in the UDM case also occurs in circumstances where the Court did not take into account, or engage in sufficient detail, the implications the establishment of a framework that would guide the Speaker's decision may have on the separation of powers doctrine. ${ }^{74}$ While the Court did consider the separation of powers to an arguably sufficient degree in deciding whether the Constitution or the Rules permit a secret ballot, it failed to engage with the implications for the doctrine of setting out certain factors the Speaker would have to consider. In this regard, in unnecessarily setting out factors that would guide the Speaker's determination on the appropriate voting procedure, the Court did not take into account any adverse consequences that its decision may have on the doctrine of separation of powers, and arguably failed to maintain an appropriate balance between ensuring "judicial supervision and accountability"75 on the one hand and showing the necessary respect to the democratically elected institution's mandate to govern on the other. ${ }^{76}$ This is even more worrying, given that the question as to when a Speaker's decision may be reviewable, and if reviewable, what standard of review would apply, has not been theorised to a sufficient degree in South African law.

At its base, the separation of powers doctrine seeks to prevent the abuse of power by placing checks and balances on the different branches of government. The question that the Court in UDM failed to address is why it was necessary to outline a potentially more rigorous form of review in circumstances where it was not clearly evident that there would be an abuse of power on the part of the Speaker. The only reason the Speaker declined to order a secret ballot was because she (although incorrectly) thought that she did not have the power to do so. In fulfilling its crucial role of placing checks on the other branches of the state, the court must also show due

\footnotetext{
72 O'Regan 2012 SAJHR 128; Price 2013 SALJ 657.

Kohn 2013 SALJ 811.

Kohn 2013 SALJ 810-836 makes this argument in relation to Albutt $v$ Centre for the Study of Violence and Reconciliation 20103 SA 293 (CC), Judicial Service Commission v The Cape Bar Council 20131 SA 170 (SCA), and Democratic Alliance. Although she does not criticise the outcome of these decisions, she is critical of the application of an "expansive conception or rationality review" without seriously considering the implication thereof on the doctrine of the separation of powers. Also see Price 2010 SALJ 582.

75 Kohn 2013 SALJ 811. 
respect to the choices made by those who occupy office in those other branches. ${ }^{77}$ If it is accepted that motions of no confidence enable the Legislature to hold members of the Executive authority accountable, and both forms of voting in that debate achieve that purpose, it may follow that the Court must show appropriate respect to the choice made as to which voting procedure to adopt in any given circumstance. ${ }^{78}$ Failure to do so may be considered an affront to the separation of powers doctrine, especially since a motion of no confidence is highly political in nature. In this regard the Court should be mindful to show the necessary respect if it is requested to review the Speaker's decision on this matter in future. Applying a stricter form of review without proper regard to the Court's institutional role may negatively impact on the relationship between the legislature and the judiciary, and hold grave implications for the separation of powers doctrine.

\section{Conclusion}

In UDM the Constitutional Court discussed certain factors that the Speaker would have to consider when deciding which voting procedure to adopt in proceedings arising from motions of no confidence. These are arguably also the factors the Court may have regard to if it is requested to review the Speaker's decision in future. However, the fact that the Court discussed certain factors that would guide the Speaker's decision raises certain questions for which the Court did not provide any plausible answers.

It is unclear whether the Court had in mind a "rationality proper"79 form of review, or whether it had in mind a more stringent form of review, almost similar to a reasonableness review in terms of PAJA. It is still rather unclear which powers/competencies of the legislature would fall under legislative functions excluded from the definition of administrative action and would therefore not be reviewable in terms of PAJA. In this regard, the failure of the Constitutional Court to consider whether the Speaker's decision would ever be reviewable in terms of PAJA is a missed opportunity that would not assist lower courts in navigating difficult cases dealing with decisions made by the leader of the elected legislative branch.

\footnotetext{
77 Bato Star Fishing (Pty) Ltd v Minister of Environmental Affairs 20044 SA 490 (CC) (hereafter Bato Star) para 46; Corder 2004 SALJ 444.

78 In Bato Star para 48 O'Regan held: "Often a power will identify a goal to be achieved, but will not dictate which route should be followed to achieve that goal. In such circumstances a court should pay due respect to the route selected by the decisionmaker."

79 Kohn 2013 SALJ 811.
} 
Furthermore, it is unclear whether the Court had in mind the same notion of rationality review it had in mind as in Democratic Alliance; that is, a more expanded notion of rationality review that leans more to the side of a reasonableness review under PAJA. Under basic rationality review a court would have to abide by the choice of the Speaker, provided that the choice was within the "range of possibilities ... [of which all] are legitimate, constitutional choices".80 The expanded notion of rationality review, however, includes questioning whether the decision maker had regard to all relevant information or whether the decision maker in fact ignored certain relevant information. In the main, this expanded notion of rationality review enables a court to consider which decision would better realise the purpose. This is surely a move away from basic rationality review, as the Speaker would have to consider whether either an open or a secret ballot will "more likely ... contribute certainly, probably, possibly, substantially or reasonably better towards achieving the purpose of voting on no confidence motions." 81

In UDM the Court stopped short of ordering a secret ballot (and rightly so), but still outlined a number of factors the Speaker must have regard to in making a decision afresh. In this regard, there was arguably no "unwarranted intrusion" by the Court into the sphere of the legislature. However, in the absence of a constitutional provision expressly providing for a secret ballot and since the legislature has the power to determine its own internal arrangements, the potential of setting aside the speaker's decision on the basis of a stricter test (and not adopting a basic rationality test) potentially makes unwarranted intrusion possible in future. It appears that in reviewing the decision of the Speaker courts may now be able to go further than simply questioning whether there is a rational link between the decision and the purpose, and maybe apply a stricter test, one that is moving closer to review under administrative law. This would be a major development in South African law, one that is in need of analytical rigor on the side of the Court, especially in so far as it may hold implications for the separation of powers doctrine.

The failure on the part of the Court to consider the implications of its judgment, even those forming part of the obiter part of the judgment, on the separation of powers doctrine shows up most clearly in the EFF decision that followed. In that decision, Chief Justice Mogoeng Mogoeng, writing a minority judgment, accused the majority of the Court of overreach. He

\footnotetext{
80 Rautenbach 2018 TSAR 14 with reference to S v Manamela 20003 SA 1 (CC) para 95.

$81 \quad$ Rautenbach 2018 TSAR 14.
} 
reasoned that the majority decision "is a textbook case of judicial overreach - a constitutionally impermissible intrusion by the Judiciary into the exclusive domain of Parliament", 82 one that is not sensitive to separation of powers concerns. Although this fundamental disagreement amongst justices in the Constitutional Court may have come as a surprise, it is perhaps explained by a sustained lack of seriously and consistently considering the implications of its judgments dealing with internal parliamentary rules and procedures on the separation of powers doctrine.

\section{Bibliography}

\section{Literature}

Banda 2018 SAIPAR Case Review

Banda T "United Democratic Movement $v$ Speaker of the National Assembly and Others (CCT89/17) [2017] ZACC 21" 2018 SAIPAR Case Review 1620

Cachalia 2015-2016 NYL Sch L Rev

Cachalia F "Judicial Review of Parliamentary Rulemaking: A Provisional Case for Restraint" 2015-2016 NYL Sch L Rev 379-406

Corder 2004 SALJ

Corder H "Without Deference, with Respect: A Response to Justice O'Regan" 2004 SALJ 438-444

Hoexter Administrative Law

Hoexter C Administrative Law in South Africa $2^{\text {nd }}$ ed (Juta Cape Town 2012)

Kavanagh 2010 UTLJ

Kavanagh A "Judicial Restraint in the Pursuit of Justice" 2010 UTLJ 23-40

Klaaren and Penfold "Just Administrative Action"

Klaaren $\mathrm{J}$ and Penfold G "Just Administrative Action" in Woolman S and Bishop M (eds) Constitutional Law of South Africa $2^{\text {nd }}$ ed (Juta Cape Town 2008) ch 63

Kohn 2013 SALJ

Kohn $L$ "The Burgeoning Constitutional Requirement of Rationality and the Separation of Powers: Has Rationality Review Gone too Far?" 2013 SALJ 810-836

82 EFF para 223. 
Okpaluba 2015 CILSA

Okpaluba C "Can a Court Review the Internal Affairs and Processes of the Legislature? Contemporary Developments in South Africa" 2015 CILSA 183-218

O'Regan 2012 SAJHR

O'Regan K "A Forum for Reason: Reflections on the Role and Work of the Constitutional Court" 2012 SAJHR 116-134

Parliament Rules of the National Assembly

Parliament of South Africa Rules of the National Assembly $9^{\text {th }}$ ed (Parliament Cape Town 2016)

Price 2010 SALJ

Price A "Rationality Review of Legislation and Executive Decisions: Poverty Alleviation Network and Albutt" 2010 SALJ 580-591

Price 2010 SAPL

Price A "The Content and Justification of Rationality Review" 2010 SAPL 346-380

Price 2013 SALJ

Price A "The Evolution of the Rule of Law" 2013 SALJ 649-661

Rautenbach 2018 TSAR

Rautenbach IM "Rationality Standards of Constitutional Review and the Risk of Judicial Overreach" 2018 TSAR 1-17

Sewpersadh and Mubangizi 2017 LDD

Sewpersadh $\mathrm{P}$ and Mubangizi JC "Judicial Review of Administrative and Executive Decisions: Overreach, Activism or Pragmatism?" 2017 LDD 201220

Van der Sijde Reconsidering the Relationship between Property and Regulation

Van der Sijde E Reconsidering the Relationship between Property and Regulation: A Systemic Constitutional Approach (LLD-thesis Stellenbosch University 2015)

Venter 2014 TSAR

Venter R "Motions of No Confidence: Parliament's Executive Check and Checkmate. Mazibuko v Sisulu 20136 SA 249 (CC)" 2014 TSAR 407-418 
Woolman 2018 CCR

Woolman S "A Politics of Accountability: How South Africa's Judicial Recognition of the Binding Legal Effect of the Public Protector's Recommendations had a Catalysing Effect that Brought down a President" 2018 CCR 155-192

\section{Case law}

Albutt v Centre for the Study of Violence and Reconciliation 20103 SA 293 (CC)

Bato Star Fishing (Pty) Ltd v Minister of Environmental Affairs 20044 SA 490 (CC)

Chairperson of the National Council of Provinces v Malema 20165 SA 335 (SCA)

Democratic Alliance $v$ President of the Republic of South Africa 20131 SA 248 (CC)

Economic Freedom Fighters $v$ Speaker of the National Assembly 20182 SA 571 (CC)

Fedsure Life Assurance $v$ Greater Johannesburg Transitional Metropolitan Council 19991 SA 374 (CC)

Judicial Service Commission v The Cape Bar Council 20131 SA 170 (SCA)

Lekota v Speaker of the National Assembly 20154 SA 133 (WCC)

Malema v Chairperson of the National Council of Provinces 20154 SA 145 (WCC)

Mazibuko v Sisulu 20136 SA 249 (CC)

Minister of Defence and Military Veterans v Motau 20145 SA 69 (CC)

National Treasury v Opposition to Urban Tolling Alliance 20126 SA 223 (CC)

Pharmaceutical Manufacturers Association of South Africa: In re Ex Parte President of the Republic of South Africa 20002 SA 674 (CC)

$S$ v Manamela 20003 SA 1 (CC) 
Tlouamma v Mbete, Speaker of the National Assembly 20161 SA 634 (WCC)

United Democratic Movement v Speaker of the National Assembly 20175 SA 300 (CC)

\section{Legislation}

Constitution of the Republic of South Africa, 1996

Promotion of Administrative Justice Act 3 of 2000

\section{Internet sources}

Constitutional Court 2017a https://collections.concourt.org.za/bitstream/ handle/20.500.12144/3901/Applicant\%27s\%20Heads\%20of\%20Argument .pdf? sequence $=27 \&$ isAllowed $=y$

Constitutional Court of South Africa 2017 United Democratic Movement $v$ Speaker of the National Assembly: Applicant's Heads of Argument https://collections.concourt.org.za/bitstream/handle/20.500.12144/3901/Ap plicant\%27s\%20Heads\%20of\%20Argument.pdf?sequence=27\&isAllowed =y accessed 31 March 2020

Constitutional Court 2017b https://collections.concourt.org.za/bitstream/ handle/20.500.12144/3901/Fifth\%20Respondent\%27s\%20Heads\%20of\% 20Argument.pdf? sequence $=73$ \&isAllowed $=y$

Constitutional Court of South Africa 2017 United Democratic Movement $v$ Speaker of the National Assembly: Fifth Respondent's Heads of Argument https://collections.concourt.org.za/bitstream/handle/20.500.12144/3901/Fif th\%20Respondent\%27s\%20Heads\%20of\%20Argument.pdf?sequence=73 \&isAllowed $=y$ accessed 31 March 2020

Constitutional Court 2017c https://collections.concourt.org.za/bitstream/ handle/20.500.12144/3901/First\%20Respondent\%27s\%20Heads\%20of\% 20Argument.pdf?sequence $=29$ \&isAllowed $=y$

Constitutional Court of South Africa 2017 United Democratic Movement $v$ Speaker of the National Assembly: First Respondent's Heads of Argument https://collections.concourt.org.za/bitstream/handle/20.500.12144/3901/Fir st $\% 20$ Respondent $\% 27 \mathrm{~s} \% 20$ Heads $\% 20$ of $\% 20$ Argument.pdf?sequence $=29$ \&isAllowed $=y$ accessed 31 March 2020 
Constitutional Court 2017d https://collections.concourt.org.za/bitstream/ handle/20.500.12144/3901/Summary\%20of\%20judgment.pdf?sequence= 90\&isAllowed $=\mathrm{y}$

Constitutional Court of South Africa 2017 United Democratic Movement $v$ Speaker of the National Assembly: Summary of Judgment https://collections.concourt.org.za/bitstream/handle/20.500.12144/3901/Su mmary\%20of\%20judgment.pdf?sequence=90\&isAllowed=y accessed 11 March 2020

\section{List of Abbreviations}

CCR

CILSA

LDD

NYL Sch L Rev

SAJHR

SALJ

SAPL

TSAR

UTLJ
Constitutional Court Review

Comparative and International Law Journal of Southern Africa

Law, Democracy and Development

New York Law School Law Review

South African Journal on Human Rights

South African Law Journal

Southern African Public Law

Tydskrif vir die Suid-Afrikaanse Reg

University of Toronto Law Journal 